\title{
Gra brył domu jednorodzinnego
}

\section{The play of solids in a single-family house}

\section{Streszczenie}

Świat architektury zmienia się, jest to dość oczywiste. Piękno tak potrzebne kiedyś jako warunek sine qua non istnienia działa sztuki unaHlo. Funkcja budujaca przez ostatnie dekady ksztatt architektury jest dzis raczej blahym pretekstem. Kompozycja

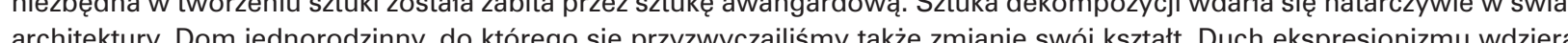
się do architektury mieszkaniowej. Nauka projektowania musi podążý nową, nie do końca znaną droga.

\section{Summary}

The world of architecture is changing, it is quite obvious. Once so necessary as a sine qua non condition for the existence of a work of art, beauty has died. Function, which has been building the shape of architecture for decades, is a rather trivial pretext today. The composition necessary to create art has been killed by avant-garde art. The art of decomposition has pushed
its way into the world of architecture. The single-family house we have become accustomed to is also changing its shape. The spirit of expressionism invades residential architecture. Design science has to follow a new, not entirely known path.

Stowa kluczowe: architektura, nauczanie, kompozycja, prace studenckie, dom

Keywords: architecture, teaching, composition, student works, house

\section{Początki}

Historycznie piękno przedstawiano w dziełach dających się wyrazic w postaci wzorów matematycznych. Budynki powstawały według zapamiętanych regut i przyzwyczajen, tak architektów, jak i odbiorcow. Ważna była poprawna kompozycja. Jednak samo określenie poprawności kompozycyjnej jest trudne do opisania i możemy zauważyć, że jest zmienne. Zajmijmy się więc rozszyfrowaniem znaczenia samego słowa „kompozycja”, słowniki nie ułatwiają nam tego. Dla architektury najbardziej interesujące wydają się okreslenia takie jak: układ, budowa, pomys dzieła sztuki, dzieło sztuki. I jeżeli potraktujemy budowę jako dazzenie do jakiegos nieokreślonego piękna, możemy odrucic okcs jenia takie jak: nauka, a interesujace moż byc: teoria komponowania dziel sztuki. I jak zawsze dla odnalezienia sensu archith dziny możemy przytoczyc slowa flozofa. Fikín Schller póci ma nam w zrozumieniu sensu poszukiwań poprawnosci kompozycyjnej, pisząc:

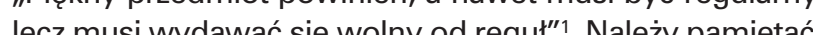
że właśni nainiekzy problod z kompozyci czy regu tami tak prostymi wy osiagnieciu w innych sztukach maja whánie architekci. Projekt domu jest zawsze obarczony podejściem funkcionalistycznym, które jest niemoiliwe do zanegowania Znowu można przytoczyć słowa filozofa wpedzajacego nas w potzzebe przedstawinia wszystio go za pomoca liczb, Arystoteles twierdzit: Istona jedności jest poczatek liczby bo pierwsza miara jest poczatkiom gdyż to, za pomoca czego poznajemy najpierw każdy ro dzaj jest pierwsza miara tego rodzaju"2. Architektura kiedyś była prosta do takiego matematycznego opisywania $W$ liczbach przedstawiany był przecież moduł konstrukcy ny, ale także powtarzalne cześći budynku czy poszczególne jego elementy. Tworzenie czytelnych układów kompo-

1. Beginnings

Historically, beauty was presented in works that could be expressed in mathematical formulas. The building were built according to memorized rules and habits of wath architects and recipients. The correct compositio was important. However, the very definition of the compositional correctness is difficult to describe and we can eee that it is variable. And so let us deal with deciphering the meaning of the word "composition" itself; dictionarles do not make it any easier for us. The most interesting terms for architecture appear to be: arrangement, construction, the idea of a work of art, work of art. And if we treat construction as an aspiration to some undefined beauty, we can reject terms such as science, whereas the theory of composing works of art may be interesting. As always to find the meaning of architecture, we can quote the words of the philosopher. Friedrich Schiller helps us understand the sense of the quest for compositionlo corechess: "The beautfiful product may, even must, be in accordance with a rule, but it must appear rule-

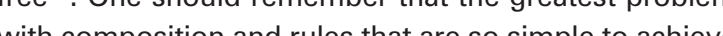

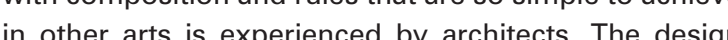
of ather arts is experienced by architects. The design a house is always bush prote the words of the philo the need to represent everything by means of number Aristotle some kind of beginning of number; for the first measre is the begining, since that by which we first know ach class is the first measure of the class" 2 . In the pas architecture was simple enough for such mathematical descriptions. After all, a structural module, but also repetitive parts of the building or its individuat elements zycyjnych było określane jako nadrzędny cel architekta. Patrząc na takie pode storyczne, możemy doszuk wac się celu w takim projekowaniu. Tu znowu który twierdził, że: „Rzeczy, które powstały przypadkiem nie powstały ze względu na coś, ani też nie mają żadnego celu; natomiast, w rzeczach, ktore powstały dzięki sztuce istnieje i cel, i przyczyna -zawsze bowiem ten, kto posiada sztukę poda ci powód, dla którego napisat i w jakim celu to uczynit - i ten cel jest lepszy niz to, co ze względu na niego powstało. [...] Zatem wszystko, co jest według sztuki, powstaje z jakiegoś powodu, i to jest najlepszym tego celem, natomiast to, co powstaje przypadkiem, powstaje bez celu. Może wprawdzie powstac coś dobrego i przypadnie jest dobre poniewa to co powstaje pryparym jest nie jest dobre, pón mi które nadia sie dostownie do opisóm sposobu projektowania jaki możemy przypisá architektom. Pojawiaja sie tu terminy jak z opisów budowlanych projektów: razem, oddzielnie, stykać sie miedzy kolejność, przyleganie iciagtość Umberto Eco poetycko tlumaczy nam potrzeb zasad kompozycyinych. Pisarz thumaczy to na podstawie procesu twórczego: Kiedy autor powiada, ze pracowa w porywie natchnienia, kłamie. Genius is twenty percent inspiration and eighty percent perspiration. Nie pamietam już, o jakim swoim sławnym wierszu Lamartine pisze że narodził sie od reki, pewnej burzliwej nocy spẹdzone $w$ lesie. Kiedy poeta umart, odnaleziono rękopisy z poprawkami i wariantami i stwierdzono, że był to być może najbardziej „wypracowany" wiersz w całej literaturze francuskiej. Kiedy pisarz (albo artysta w ogölności) mówi, że pracował nie mysiląc o regułach procesu twórczego, chce tylko powiedziec, ze pracował nie wiedząc, iż zna owe reguły"s. Mozzna odniesc to do architektury. Nawet negujący zasady kompozycji tworcy awangardy może po prostu ni do końca je rozumieli lub znali. Architektura jako sztuka związana z techniką i koniecznością budowania nie może oderwac się od wszystkich regul i zapisu liczbowego. Je funkcja, bez ktorej nie może się obejść, uniemożliwia to lub przynajmniej utrudnia.

Twórcy od zawsze starają się zwalczać zapamiętane reguły albo chociaż umniejszać ich wagę. Hyppolytowi Tainow jako pisarzowi prościej było stawiać sądy bardzo stanow cze: "Jestze to wystarczającym i czy można twierdzic, iz dzieta sztuki ograniczaja się po prostu odtwarzaniem stodzioj whóni przhajniaj, gdyż najwiękzze szkoly najbarekci staraja sie wiec wspótcześnie przinaczać" pewnkzztty jednak przeznaczenie budynków z ich salami konferencyjymi czy kinowymi staranne im to uniemojiwi. Zewnetrzność budynków może być wspótcześnie abstrak cyinie dowolna formy wewnetrzych pomieszczé jeszcze długo pozostana tradycyine i niezmienne.

Powracając do klasycznego podejścia do projektowania należy zastanowić się nad składowymi kompozycii. Maria Gołaszewska, pisząc o dbałości o „poprawność kompozycyjną", wylicza najważniejsze zasady: „[...] symetria, równowaga, zwartość, jedność w różnorodności itp. Kompozycja dzieła w szerszym znaczeniu (dbałość o przejrzyste struktury) obejmowała też takie zasady jak jedność miej- were presented in numbers. The creation of clear compositional arrangements was defined as the architect's overarching goal. When we look at such an approach, strongly historical nowadays, we can find a goal in such design. Once more, we should refer to Aristotle, who claimed that: "Things that have arisen by chance have purpose in turn, in things that have bee they have any purt, there is both an aim and a cause-because the on who has art will always give you the reason for which he wrote it and for what purpose he did it - and this aim is better than what it has created. [.] Thus, everything that is according to art is created for some reason, and this is the best aim; and what is created by chance is created without an aim. Although something good may arise by chance, but as it is by chance and due to chance, is not good, because what arises by chance is always undefined". In Physics, he dealt with terms that are literally suitable for the descriptions of the design method that we can assign to architects. The terms appear here as in the descriptions of construction projects: together, separately, in contact, between, sequence, adhesion composition principles in a poetic way. The writer explains this on the basis of a creative process: "When the author tells us he worked in a raptus of inspiration, he is lying. Genius is one per cent inspiration and ninety-nine per cent perspiration. Taking about a famous poem of his, I forget which, Lamartine said that it had come to him in a single flash, on a stormy night, in a forest. When he died, the manuscripts were found, with revisions and variants, and the poem proved to be the most "worked vitu in all of French literature. When the writer (or the

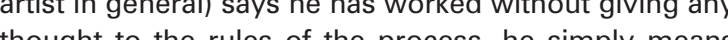
tha wa the rules of the process, he simply means This can be applied to architecture. Even the creators of who negate the rules of composition, may have simply not fully understood or knew them. Architecture as an art connected with technology and the necessity of construction cannot be separated from all the rules and numerical notation. Its function, which it cannot do without, makes this impossible or at leas cifficult. Cast to invalidate them. It was easier for Hippolyte Taine as a whiter, to make very firm judgments: "Does this sufpre us? Do we find works of art simply confined to a refor the gref the relationships of parts? By no means, 列 " "modify" certain shapes, but the purpose of b tiyings with their conferenes, br crine purpose of build prevents them from doing so. The exterior of buildings can be abstractly arbitrary nowadays, while the forms of internal rooms will remain traditional and unchanged for long time to come.

Returning to the classical approach to design, one should consider the components of the composition. Maria Gout the care for "compositional correctness" nity in diversity, etc. The composition of the work in
nitis 
sca, czasu i akcji (w teatrze), rytmiczność (w muzyce: allegro - largo - allegro), cyklicznośc (w poezji i w muzyce), powieści, teatrze, filmie)" $)^{\prime \prime}$. Zasady te nawet opisywan przez autorkę jako niezwiązane z budowaniem nadają sie doskonale do opisu architektury. Samą „rytmiczność" czy "cykliczność" możemy odnaleźć w projektach architektonicznych i przecież tak samo nazywać.

Współczesność zrywająca z takim podejściem do tworzenia czy projektowania tworzy nowe określenie - dekompozycja. Jak może się wydawać, nie oznacza ono jednak niszczenia kompozycji, lecz jest związane z jej całkowitym brakiem. Architekci sami wdają się $w$ takie dyskusje. Jo sef Paul Kleihues trochę nas prowokuje i nawołuje: „[.... poorii i a rystycznch bodźćw, [...] ich prowokująych

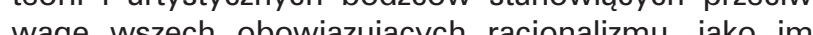

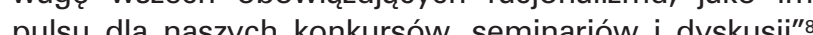
Taki manifest" może prowadzić nas do myśli o dażeniu do zerwania z kompozycia i póiściu droga ku niezeniu dekonstrukcji. Nie jest to droga tatwa a w architekture domu czasem niemożliwa Nowe podejście do tweturze domickury może być jednak antyteza stów Ad torzenia sa, który twierdzit, że każde dzieło sztuki ma swe sur Loosa, który twierdzil, ze „każde dzieło sztuki ma swe surowe,
wewnetrzne prawa i daje sie przedstawić tylko w jedne wewnętrzne prawa i daje się przedstawic tylko $\mathrm{W}$ jedne tów Wydziału Architektury PK mogą być tego przykładem. Forma współczesnej architektury pozbawiona jes wewnętrznych praw, stara się zerwać z zapamiętanym formami i przedstawić nie tylko w jednej formie.

Jednak cały opis jak budowana powinna być architektura, można przedstawić, przywołując słowa Le Corbusiera, który twierdzit, że: „Architektura to przemyślana bezbłędna, wspaniała gra brył w świetle

\section{Nauczanie}

I tu pojawi się problem przełożenia teorii architektonicznych i marzeń filozofów na język zrozumiały dla studentów pierwszych lat studiujących na wydziale architektury. Te matem cwiczenia na 4 semestrze 2 roku studiów jest DOM Należy zaprojektować dom jednorodzinny, wolno stojący, usytuowany na wskazanej dziatce. W pobliżu miasta, wodległości, która uwalniając od uciążliwości gwaru, ruchliwości, nieprzewidzianych spotkań i zwykłej ciekawości, pozwala jednak zachowac miejskie obywatelstwo i uczest-
niczyć w życiu tej społeczności - powstanie DOM. Teren niczyc w zyciu tej spotecznosci- powstanie DOM. Teren
wybrano starannie. Znacznej rozlegtości obszar przeznaczony na budowę domu i przydomowy park, obejmuje niewielkie wzgórze z tagodnym, nastonecznionym stokiem o zauważalnych różnicach wysokości terenu. Obok tereny rolnicze; dalej niewielka rzeka. Sytuacja oferuje wglądy w okolice i dalekie widoki, dopóki drzewa w planowanym parku nie zapewnią większej intymności, osłaniając dyskretnie dom od nieprzewidywalnego sasiedztwa Dojazd i dojście możliwe są od strony drogi w najniżej położonej z rozkładem pomieszczeń i ich wymiarami. Całość zadania została nazwana, podazając za nauka Le Corbusiera: GRA BRYL - DOM W KRAJOBRAZIE - ARCHITEKTURA BETONOWA. Najtrudniejszy wydaje sie chyba pierwszy człon. Gra brył jest trudna do opisania, ale staje się intelek- a broader sense (care for transparent structures) also per go - allegro), cyclicality (in poetry and in music), time sequence according to natural chronology (in the nove, heatre, film) "These principles, even those described by the author as unrelated to construction, are perfec "cyclicality" can be found in architectural projects and can be called the same way.

Contemporary times, which abandon such an approach Creation or design, create a new term - decomposition. As it may seem, however, it does not mean destroying the . tects themselves engage in such discussions. Josef Pau Kleihues provokes us a little, exhorting: "[...] We need the energy of outsiders, [...] their provocative theories and aristic incentives that counterbalance all prevailing rationalism, as an impulse for our competitions, seminars, and discussions" ${ }^{\text {". }}$. Such a "manifesto" may lead us to think about striving to break with the composition and follow the path towards an unknown deconstruction. It is not an ent impossible. However, a new approach to the creation of Los, who claimed that "each work of art has its own stric internal laws and can only be presented in one form"s Single-family houses designed by students of Architeture at Cracow University of Technology can serve as a example of this. The form of contemporary architecture is deprived of internal rules, it tries to break with memorized forms and present them not only in a single form.

However, the entire description of how architecture should be built can be presented, referring to the words of Le Corbusier, who claimed that: "Architecture is the masterly, correct and magnificent play of solids brought together in light"

\section{Teaching}

The is where the problem of translating architectura theories and dreams of philosophers into a language HOUSE is a topic of the exercise in the $4^{\text {th }}$ semester in the $2^{\text {nd }}$ year of studies. One is required to design a single-family, detached house situated on the indicated plot. In the vicinity of the city, at a distance that eliminates the nuisance of hustle and bustle, unforeseen meetings and ordinary curiosity, but allows one to citizenship and participate in the life of this community - the HOUSE will be created. The plot has been carefuly selected. The vast area dedicated to the construction of the house and the adjacent park includes a small hil with a gentle, sunny slope and noticeable differences in height. Nearby agricultural land; further a small river. The situation offers insights into the surroundings and distant views untis ins trees in the planned park provide more intimacy, discreetly shielding the house from the trians and vehicles are possible from the roadside in the lowest part of the site. Then the required function is described along with the layout of the rooms and their dimensions. The whole task was named after Le Corbusier's teachings: PLAY OF SOLIDS - HOUSE IN THE tualnym pretekstem dla budowy formy architektonicznej. Nalezy pamiętac, ze zabawa jednak jak opisuje ja Joha Huizinga, i jest czy ź zu "sama stanowi podstawę i czynnik kultury"10. I co moż być najważniejsze dla architektów, zabawa musi mieć nie zmienne reguly. Muszą one byc jednakowe dla wszystkich co pomoże nauczycielom w ocenie końcowej projektów studenckich, a im samym ułatwi poprawne wykonani projektu budowlanego. Pojawia się jeszcze jedna myśl, że "W obrębie miejsca zabawy panuje swoisty i bezwarunkowy porzadek. Slowa te možna uznac $w$ projektowani za potrzebę jasnej i widocznej kompozycj. Jednak $w$ arch ekturze wspołczesnej nie jest to już rzeczą oczywistościa a może nawet niemodną, precyzyjny i zrozumiały. Tu maja powstać projekty "szalone", jednak nadające się do zbuprzeciez architektura mieszkaniowa. A jednym z celów ćwiczenia jest nauka realnego podchodzenia do projektowania nawet najbardziej nierealnych domów, w pracach studentów powstan one wszak tylko na papierze. Nasza zabawa ma składać sie przynajmniej z gry dwóc bryt Są one dowolnie dobierane przez studentów i wypełnione odpowiednia funkcią zgodnie z precyzyjnym założeniami. Bryły mają połączyć się $\mathrm{w}$ całość prostą do słownego opis Współcześnie jesteśmy w okresie wszechobecnej architektury dekonstruktywizmu. Powoli następuje jej koniec jednak abstrakcyjne podejście do tworzenia działa i zerwanie z zapamiętanymi kształtami domów wpływał。 na kolejne pokolenia młodych architektow i chyba szybko nie zostanie zapomniane lub całkowicie zanegowane. Ksztalt tradycyjnego domu jednorodzinnego nawe w modernizmie byl jednak dosc jednoznaczny. Terazniejszość zrywa z takim podejściem do projektowania. Sztuk ekspresjonistyczna mająca wielki wpływ na architekturę dzisiejszą przyniosła nowe możliwości kryjące się z kolorem i ksztattem i mogla wyzwolic się z oczywistośc bezpośredniego tematu dzieła. To samo stało się z obrazem domu, nie musi on juz przypominać "domu”, może stać się wielka ekspresjonistyczą rzeźbą, oczywiście, jezeli takie jest zyczenie inwestora. Jak możemy zobaczyc funkcja, jaką niesie architektura mieszkaniowa, może byc przedstawiona w downy sposob. Temat prac studen-

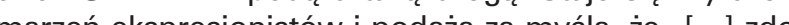
bycza wspótczesnego ekspresionizmu stato sie odkrycie że kompozycje abstrakcyine moga równie dobrze stużć celom ekspresii, jak obrazy vtematyczner. Okazato sie ż można catkowicie zrezygnować z tematu, który przeciez czesto pełnit dotychczas role nośnika emocji w akcie eks presji (jakby łatwo przyswajalnej polewy cukrowej wokó gorzkiej pigutki znaczenial. Że zupełnie może wystarczyc siła wymowy kolorów i ksztattów, uderzeń pedzla, fak tury, wymowa rozmiarów i skali dzieła"12. Przeznaczenie domów z czwartego semestru studiów jest dla niewprawnego obserwatora trudne do odkrycia. Jednak takie podejście do budowy formy architektonicznej i podejście abstrakcyjne do jej ksztaltów niesie w sobie możliwos
LANDSCAPE - CONCRETE ARCHITECTURE. The hardest part seems to be the first segment. The play of solids is difficult to describe, but it becomes an intellectual pretext for building an architectural form. The play itself can be trivially translated as fun. Nevertheless, it should be remered that play, as Johan Huizinga describes it. is something quite serious. Pure play "is itself the baimportant for arche play must have une the most rules. They must be the same for everyon which wil help the teachers in the final evaluation of the student projects, and thus facilitate the correct execution of the construction project for students. There appears another thought that "inside the play-ground an absolute an peculiar order reigns"111. These words can be considered in design as a need for a clear and visible composition. However, in contemporary architecture it is no longer an obvious thing, and perhaps even unfashionable one. As future architects, students must present the thoughts in a very precise and understandable way. This is where "crazy" projects are to be created, bu they must be suitable for construction without incurring One of the aims of the exercise is to learn how to ap-
One proach the design of even the most unrealistic houses in a realistic way, after all, in the student works they will be created only on paper. Our play is to consist at least two solids. They are independently selected by students and filled with an appropriate function according to precise assumptions. The solids are to be combined into a whole that is simple

ways, we are in a period. structivism architecture. It is slowly coming to an end but the abstract approach to creating a work of art and the break with the memorized shapes of houses have affected successive generations of young architects and most probably will not be forgotten or completely negated quickly. The shape of a traditional single-famThe The present is abandoning was approach to design. Expressionist art, which has a great influence on conden beneath the colour and shape and could liberate itself from the obviousness of the direct theme of the work. The same happened with the image of the house, it no longer has to resemble a "house", it can become a great expressionist sculpture, naturally, if the investor architecture can be presented in any possible way. The topic of student works PLAY OF SOLIDS follows this path. It becomes the manifestation of expressionist dreams and follows the idea that " $[. .$.$] the achievement$ fiscovery that pres of exthat it was poll as intematicr paintings. It turned out which, after all, had often played the role of a carrie motions in the act of expression (as if an easily digestble sugar coating around a bitter pill of meaning). That strokes, textures, the expression of and shapes, brus work can be sufficient"12. The purpose of the houses 
tworzenia nowych dynamicznych dzieł sztuki, co możemy

Całość założenia ma znajdować się na dużej działce, jest to kolejna część tematu - DOM W KRAJOBRAZIE, otoczone terenami zielonymi $w$ niedalekiej odległości od niewielkie rzeczki. Sytuacja oferuje wglądy w okolicę i dalekie widok dopóki drzewa w planowanym parku nie zapewnią większej intymnosci, oslaniając dyskretnie dom od nieprzewidywalnego sąsiedztwa. Dojazd i dojście możliwe są od strony drogi w najniżej położonej części terenu. Na terenie istnieje sieć wodna, elektryczna, telefoniczna, gazowa brak sieci kanalizacyjnej i ciepłowniczej. Dokładnie okreslony przez "inwestora" program funkcjonalny ma ułatwic

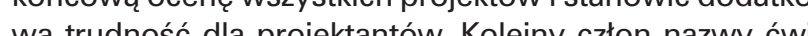
cza tri ARCHITEKTURA BETONOWA O potzebie zwróceni uwa studentów na walery mate riału budowlanego który staje sie wspótczénie szczególnie atrakcyiny w nowych grach i umozlimia nadanie prawie dowolnego ksztttu architekturze Role jaka odgrwa beton w tworzeniu budynków nowe. Role, jaką odgryw

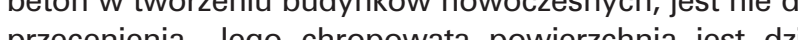
odbierana jako element estetyczny, bez pejoratywnych konotacii. Architektura zawsze poszukiwała środków materialnych, które pozwalałyby twórcy na dowolne kszattowanie budowli. Tu beton staje sie nowym, lecz tatwym do obróbki kamieniem, a jego wszechstronność powoduje że staje się wspótcześnie nie tylko materiałem konstrukcyjnym. Przychylne zainteresowanie twórców i odbiorców architektury pokazuje jakie możliwości stwarza beton w tworzeniu "nowych" dział sztuki.

Jednak należy pamiętac, ze jest to architektura "studencka" i pomimo podobieństwa do otaczajacej nas "latającej architektury" musi nadawac się do oceny i porownan. I znowu mozna przy oczc cyta , diekna ompozycja polega na rówhowadze pelni i proźni, plam cienny i jasnych, linii prostych, łamanych i krzywych [...]"13. Tu ksztalt papierowej architektury tworzą bryły, płaszczyzny, linie i punkty. Bryly i plaszczyzny wyrastają z zielo nego terenu, stają się całkowicie realistyczne dzięki malowanym perspektywom $i$ komputerowym wizualizacja Starają się byc one odpowiedzią i wyrazem tematu: GRA BRYL - DOM W KRAJOBRAZE - ARCHIEKTURA BETONOWA. PIZE STW W może dopomóc w odpowiedzi na py

\section{Zakończeni}

Odejście w ćwiczeniu od zapamiętanego obrazu domu jednorodzinnego $z$ czytelnymi elewacjami i pudetkowym ksztattem może być wyrazem oderwani od dażenia do kompozycii i uporzadkowania dzieła architektury. Herbert Read pomaga nam troche w wyttumaczeniu niestandardowych kszatáów, oskarża: Wzgledy psychologiczne, które skłaniając artystę (i artyste w każdym z nas) do wypowiadania sie poprzez uporzadkowane układy sa niejasne, chociaż niewatpliwie dadza sie psychologicznie wytłumaczyć. Ale instynkt, który skłania nas do umieszczania niepotrzebnych guzików na ubraniu, dobierani skarpetek do krawatów i kapeluszy do palt, umieszcza- from the fourth semester of studies is difficult to discovproach to building an absitectural form and an abstract pproach to its shapes brings with it the possibility of

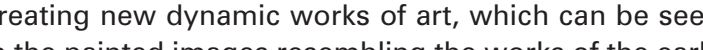
the painted images resembling the works of the early int

the the $S C A P E$, surrounded by green areas in close proximity a small river. The situation offers insights into the surroundings and distant views until the trees in the planned ark provide re intmacy, discreetly shielding the house from the unpredictable neighbourhood. Access routes for pedestrians and vehicles are possible from the roadside in the lowest part of the site. There is a water, electricity, elephone and gas network in the area, but no sewerage or heating network. The functional programme, precisely defined by the "investor", is intended to facilitate the fin assessment of all projects and to pose an additional diff-

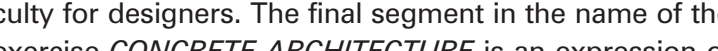
the belief in the need to draw students' attention to dvantages of the building material that is becoming perticularly attractive in new plays today and allows to give almost any shape to architecture. The role that concrete plays in the creation of modern buildings cannot be overstimated. Today, its rough surface is perceived as an aesthetic element without any pejorative connotations. Architecture has always looked for material means that would allow the creator to freely shape the building. Here, concrete becomes a new, yet easily workable stone, and its versatility makes it more than just a construction materia today. The favourable interest of creators and recipients of architecture shows what possibilities concrete offers creating "new" works of art.

列 "flyinecture and, despite its similarity to the surrounding comparison. A Aain, one can guote: "A beautiful composition is based on the balance of fullness and emptiness, dark and bright spots, straight, broken and curved lines [... 1"13. Here the shape of paper architecture is created by solids, planes, lines, and points. Solids and planes grow out of the green area, they become completely realistic thanks to painted perspectives and computer visualization. They try to be the answer and expression of the topic: PLAY OF SOLIDS - HOUSE IN THE LANDSCAPE CONCRETE ARCHTECTURE. Presenting the drawings to non-professionals may help to answer the questio

\section{. Conclusion}

A departure from the memorized image of a single-family house with clear façades and a box-shaped shape may be an expression of a detachment from striving for composition and order in the work of architecture. Herbert Read ids us a ing: The spontaneous motives that lead an artist (and the artist in all of us) to express himself in formal patterns are bscure, though no doubt they can be explained physiologically. The instinct hat leads us to put un aed essary buttons on our clothes, to match our socks and ties or hats nia zegara na środku półki nad kominkiem a pietruszki dokoła pieczeni baraniej - jest inieuczonych poruszen tego samego instynktu, który wien system uporzadkowany"14. Jak widzimy podejście prezentowane $w$ tym ćwiczeniu o zerwania z kanonami nie jest wynalazkiem całkiem nowym.

W ocenie projektów studentów z Wydziału Architektury Politechniki Krakowskiej pomocne mogą być także słowa Heinricha Wölfflina, który pisał: „Każde dzieło sztuki jes czymś tak uformowanym, jak organizm. Jego najbardzie istotną cechą jest charakter konieczności: nic nie moż być zmienione ani przesunięte, lecz wszystko musi byc takie, jakie jest . Zdania te mogą być najpiękniejszym

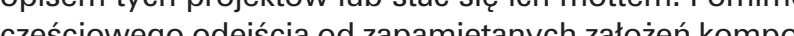
cycij moga stá́ sie one driehami sztuki samymi w sobie.

Prezentowane przez studentów projekty zostały wykonane w ramach Projektowania Architektoniczno-Urbanistycznego, 2 rok, 4 semestr - Architektura Betonowa - Gra Brył - Dom w krajobrazie 2018/2019 w Zakładzie Architektury Mieszkaniowej i Kompozycji Architektonicznej Instytutu Projektowania Architektonicznego Wydziału Architektury Politechniki Krakowskiej.

Zespó prowadzący zajęcia projektowe: dr arch. Przemysław Bigaj, dr arch. Marek Początko, arch. Piotr Stalony-Dobrzański, dr arch. Monika Gała-Walczowska

PRZYPISY

F. Schiller, Kallias, czyli o pieknnie, Kẹty 2006, s. 48

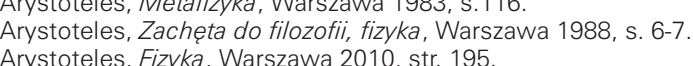

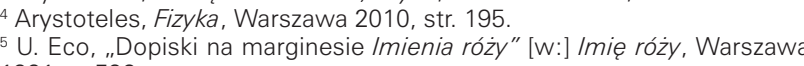
1991, S. S96.
6 H. Taine, Filozofia sztuki, Gdańsk 2010, s. 26. lody, teorie, Warsza

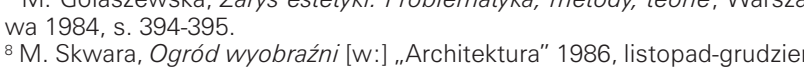
Mr. Skwara, ogród wyobraźni [ [w: ], Architektura "1986, listopad gradzie

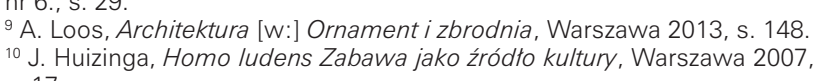

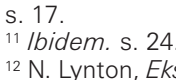

2N. Lynton, Ekspresjonizm, [w:] Kierunki i tendencie sztuki nowoczesne,

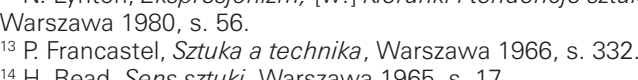

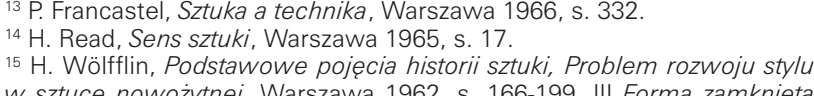
W. Situce nowoziytnej, Warszawa 1962, s. 166-199, III Forma zamknieta
iforma otwarta.

LTERATURA

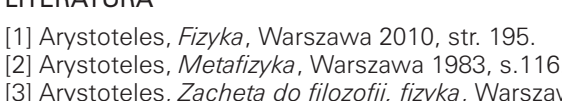

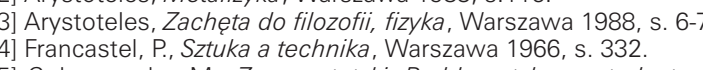

5] Gotaszewska, M., Zarys estetyki. Problematyka, metody, teorie, War-

[6] Huizinga, J., Homo ludens Zabawa jako źródto kultury, Warszawa 2007.

77] Le Corbusier, Trzy przypomnienia, bryta, [W:] W strone architektury

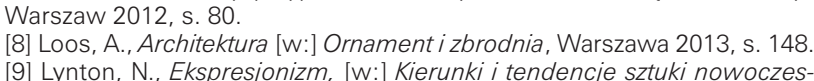

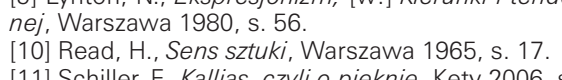

[10] Read, H., Sens sztuki, Warszawa 1965, s. 17.
$[11]$ Schiller, F, Kallias, czylio pieknie, Kety 2006, s. 4
(112] Taine, H., Filozoofia szztuki, Gdańsk 2010, s. 26.

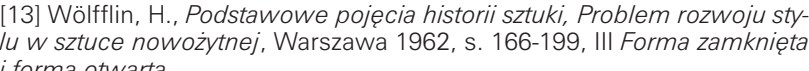

and coats, that makes us put the clock in the middle of the primitive and uneducated stirrings of the instinct that makes the artist arrange his motives in a pattern"14. As we can see, the approach presented in this exercise abo breaking with canons is not a completely new invention. Jty of Architecture at Cracow University of Techology, the following words by Heinich Welfflin can also be helpful: "Every work of art has form, is an organism. Its most essential feature is the checter of inevitability that nothing could be changed or moved from its place, but that all must be as it is"15. These sentences can be the most beautiful description of these projects or become their motto. Despite a partial departure from the memorized assumptions of the composition, they may become works of art in themselves.

The projects presented by students were made as a part of Architectural and Urban Design 2nd senester 2nd year andscape 2018/2019 in the Chair of Housing and Architectural Composition Institute of Architectural Design Faculty of Architecture Cracow University of Technology Początko, arch. Piotr Stalony-Dobrzański, dr arch. Monika Gała-Walczowska

ENDNOTES

F. Schiller, Kallias, czyli o pieknie, Kẹty 2006, p. 48.
2Arystoteles, Metatizzka, Warszawa 1983, p. 116.

ozofii, fizyka, Warszawa 1988, pp. 6-7.

.

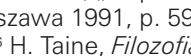

M. Gotaszewska, Zarys estetyki. Problematyka, metody, teorie.

"M. Skwara, Ogród wyobrażni [in:] „Architektura" 1986. listopa

-grudzień no. 6.; p. 29. [in: Ornament i zbrodnia, Warszawa 2013.

J. Huizinga, Homo ludens Zabawa jako źródto kuttury, Warszawa

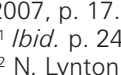

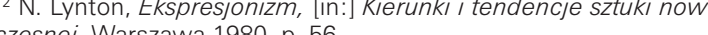

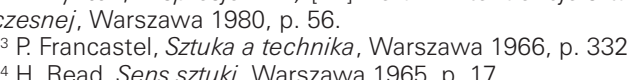

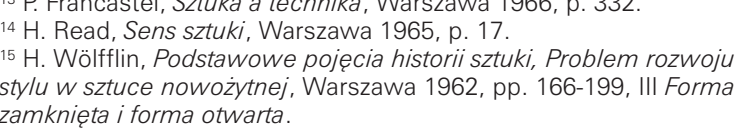

BIBLIOGRAPHY

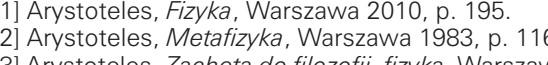

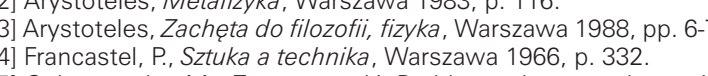
5] Gotaszewska, M., Zarys estetyki. Problematyka, metody, teorie. [6] Huizinga, J., Homo iudens Zabawa jako źródto kultury, Warsza-

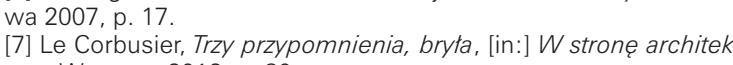

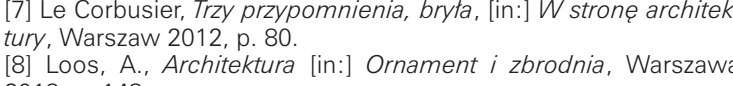
2013, p. 148. . Ekpresionizm. [in: Kierunki itendencie sztuki nowo czesnej, Warszawa 1980, p.56.
[10] Read, H., Sens sztuki, Warszawa 1965, p. 17.
[11] Schiller, F., Kallias, czyli o pieknie, Ketv 2006, p.

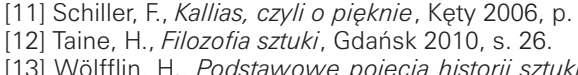

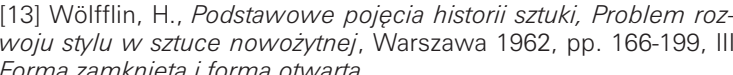



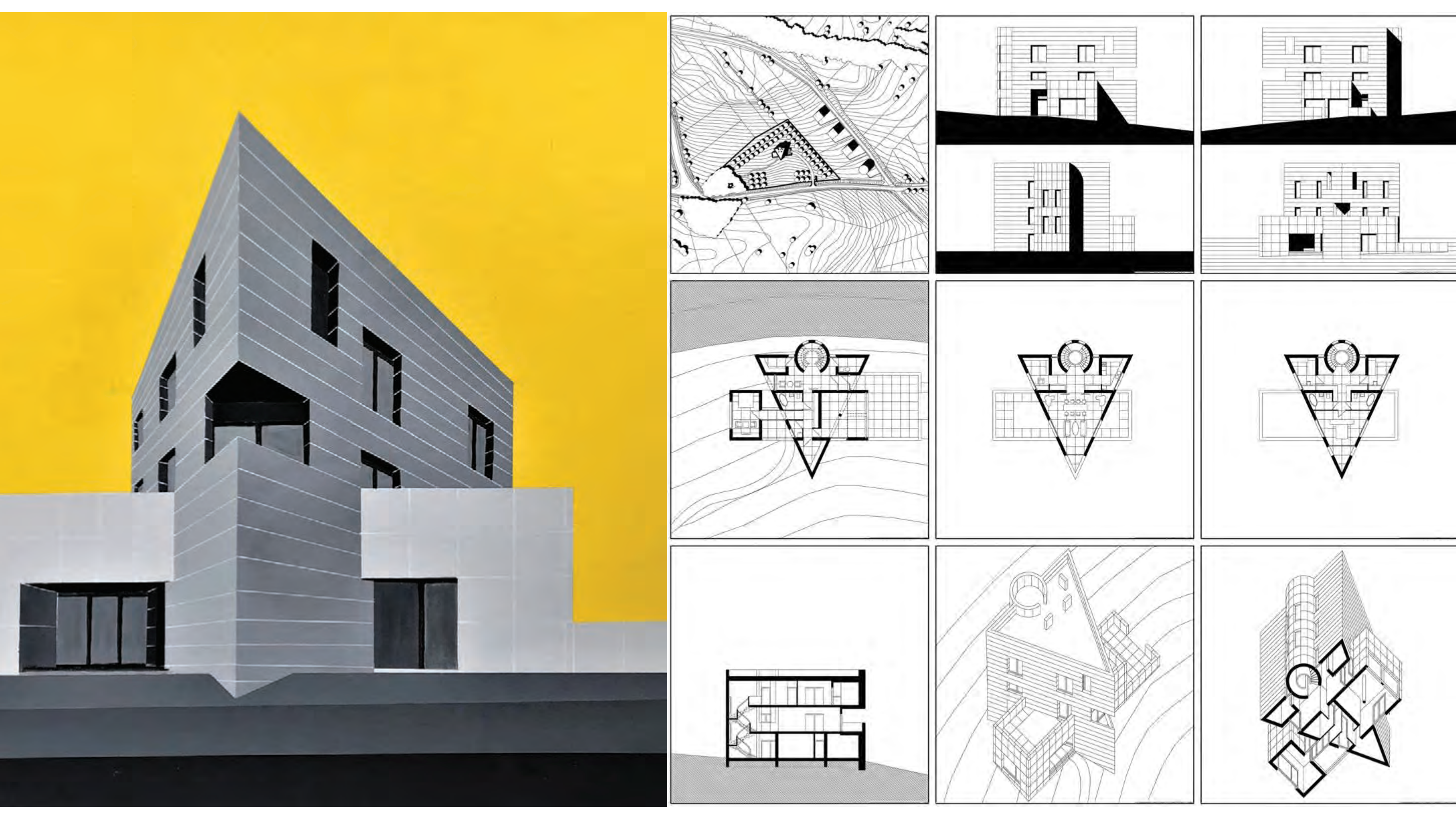


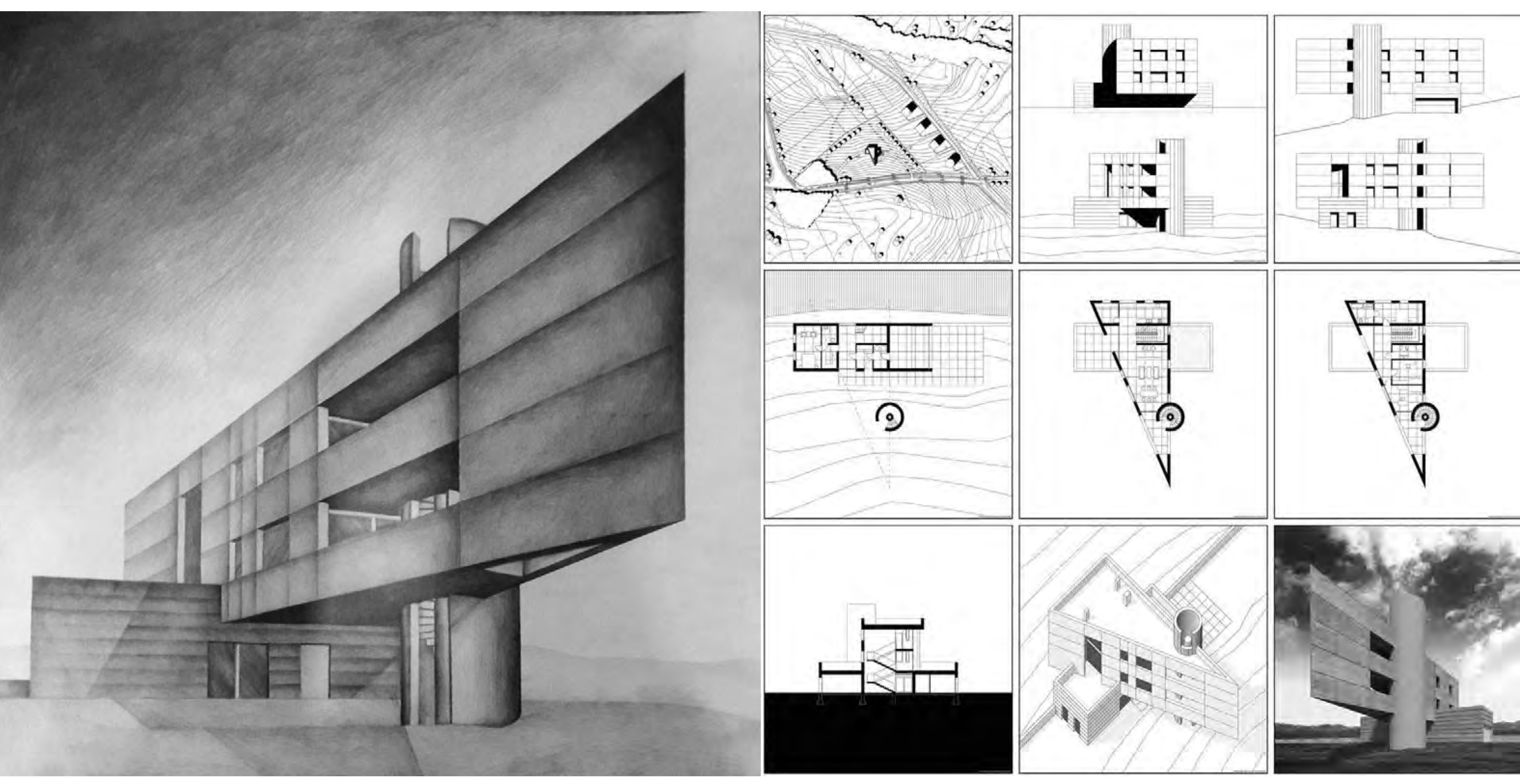




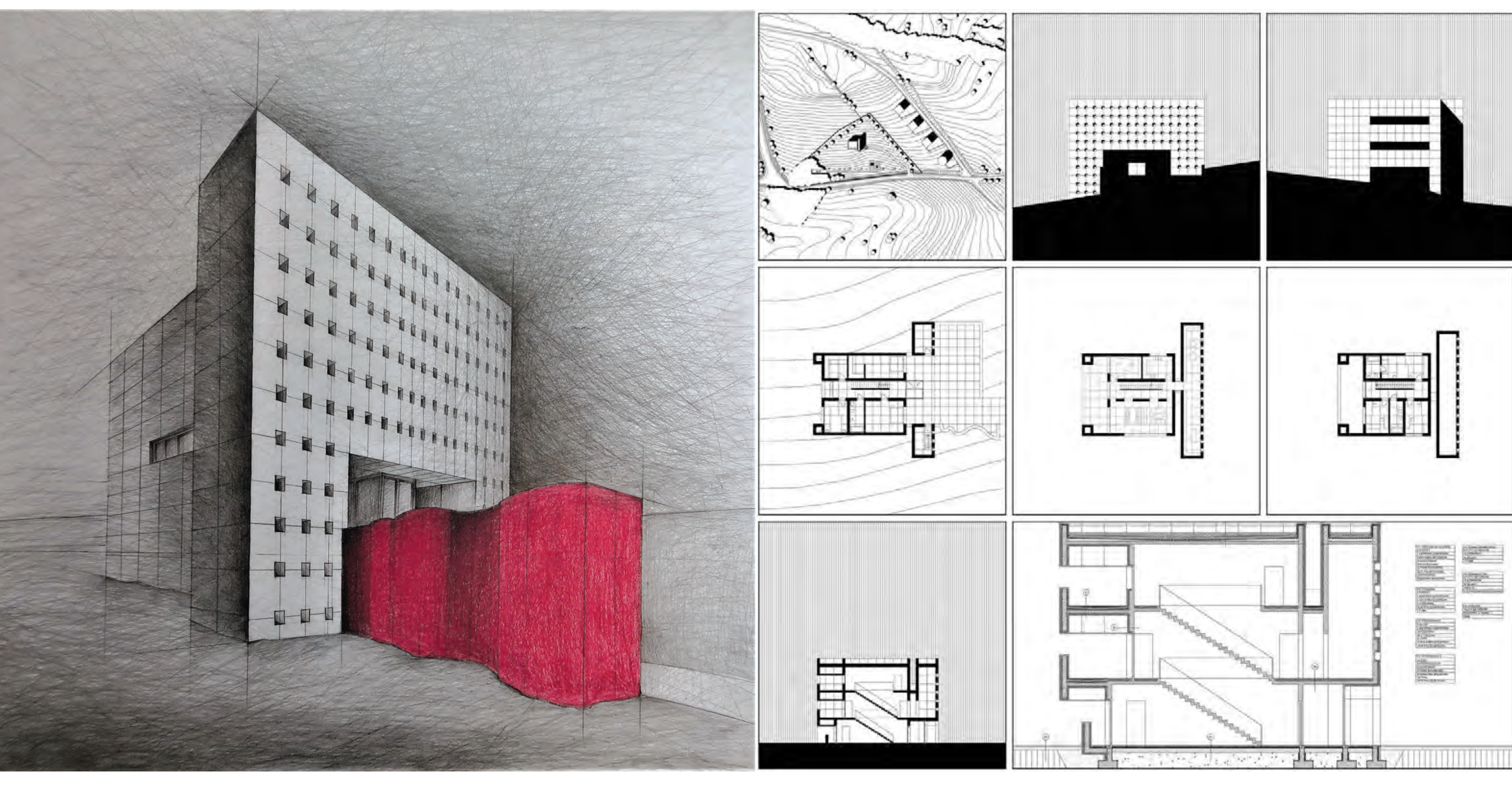




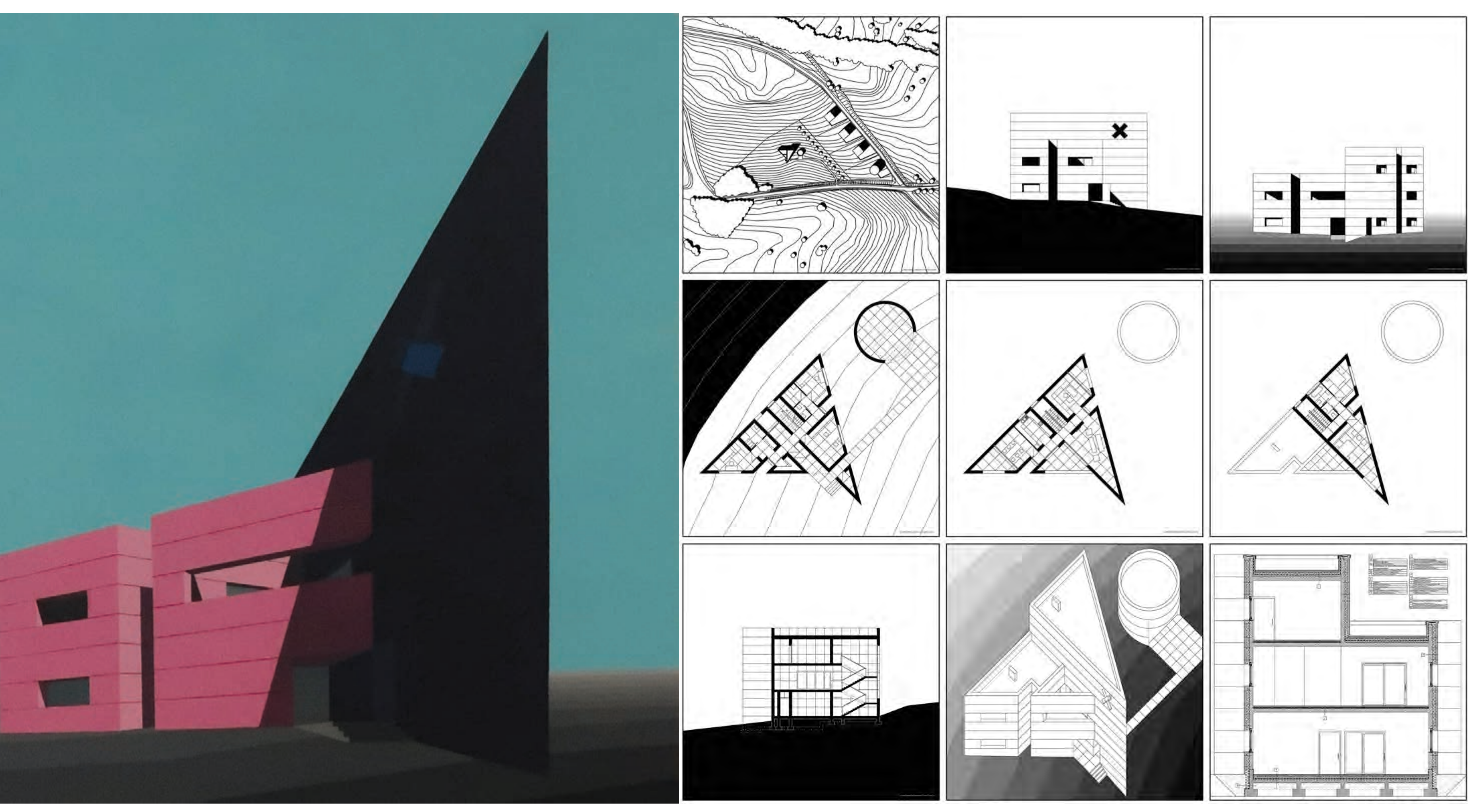



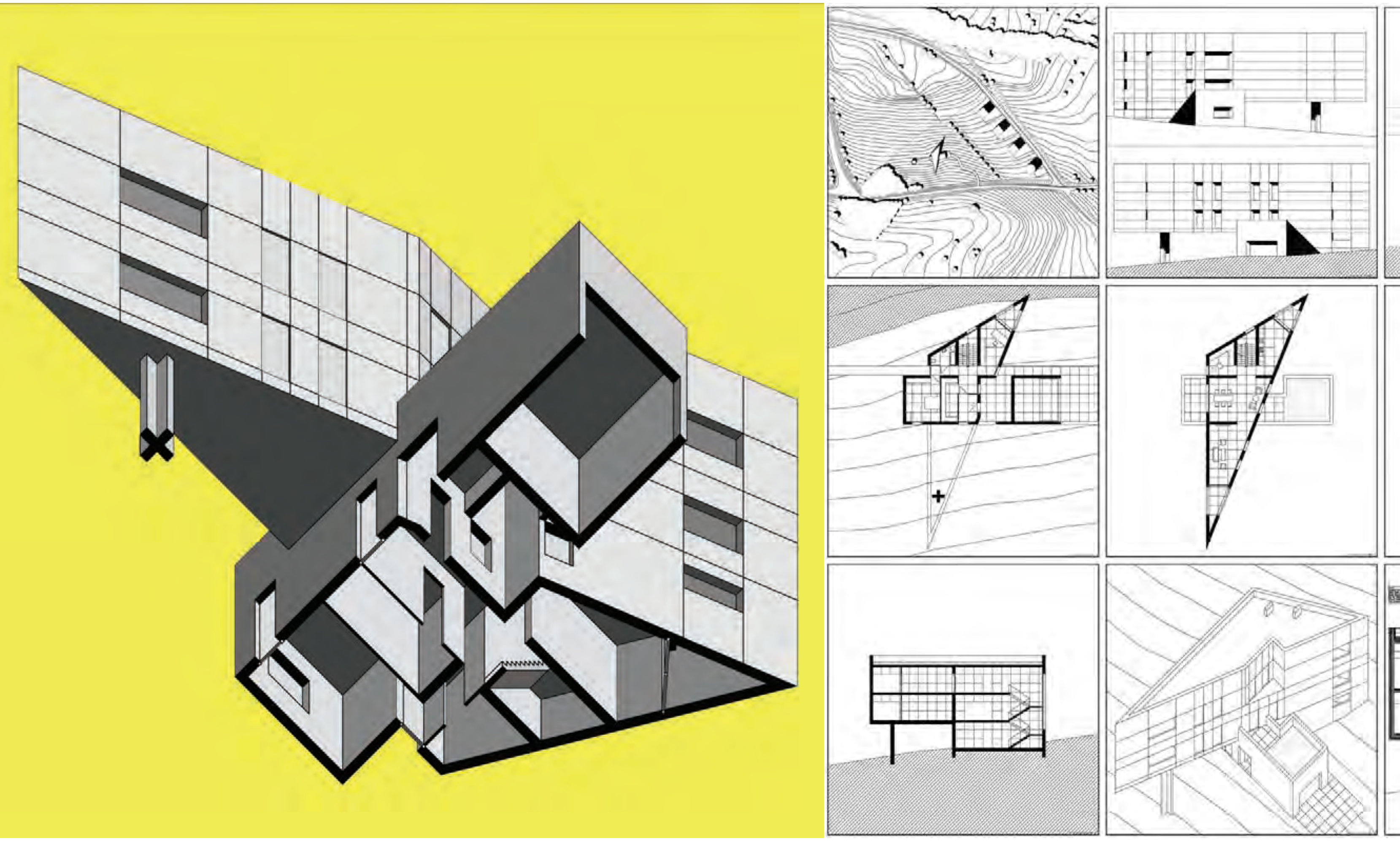

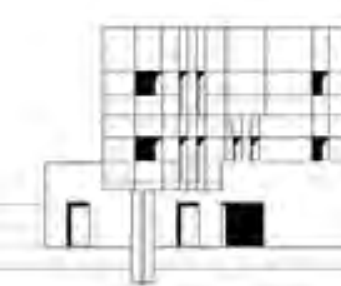

$\frac{1}{-}$

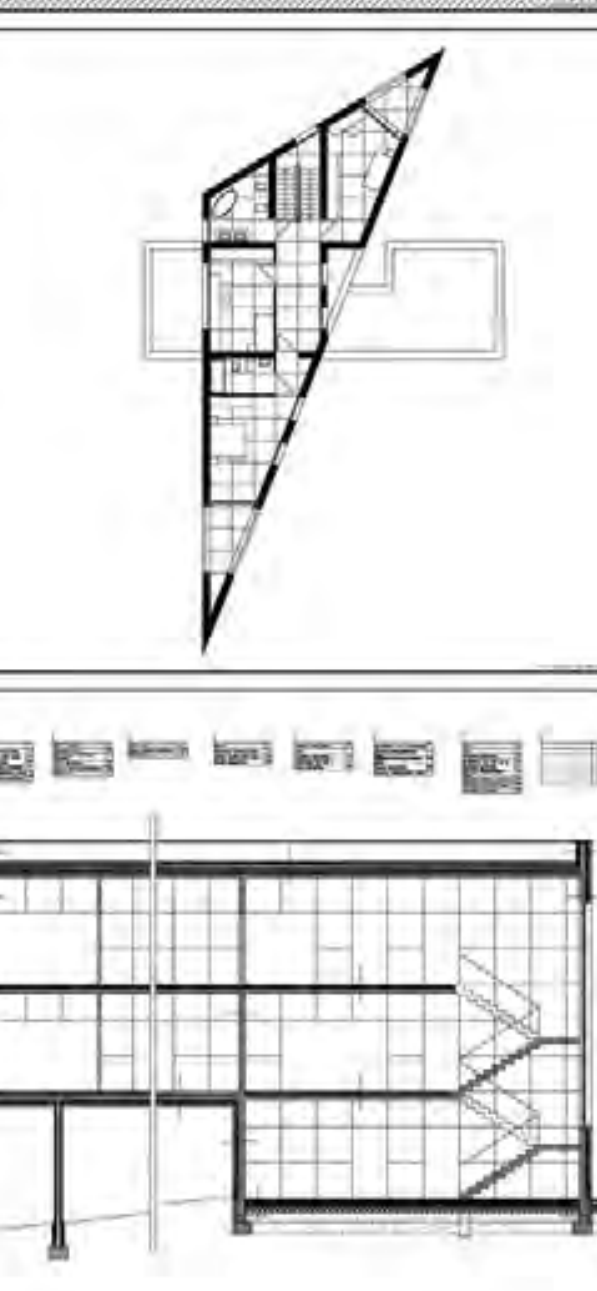




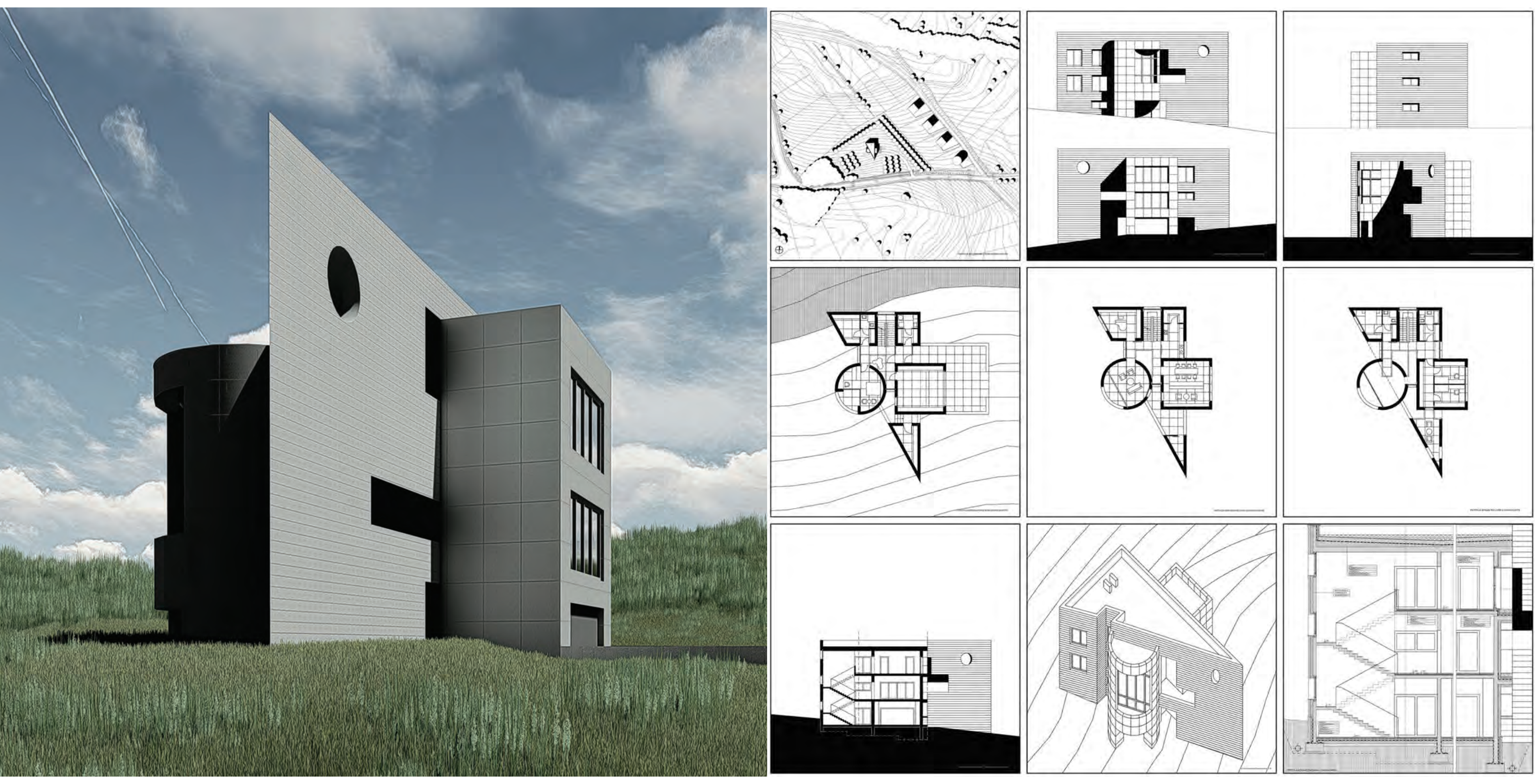



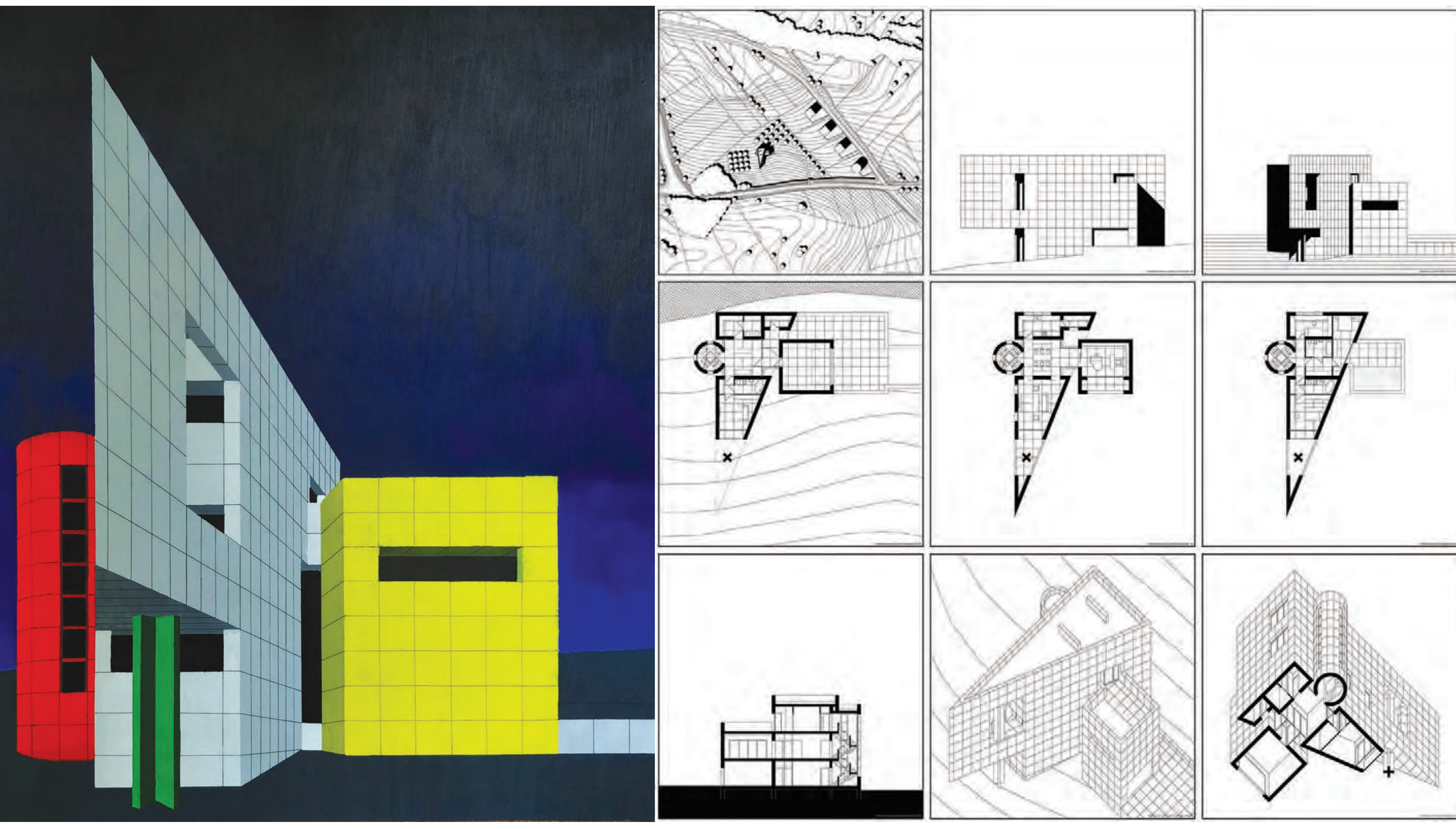


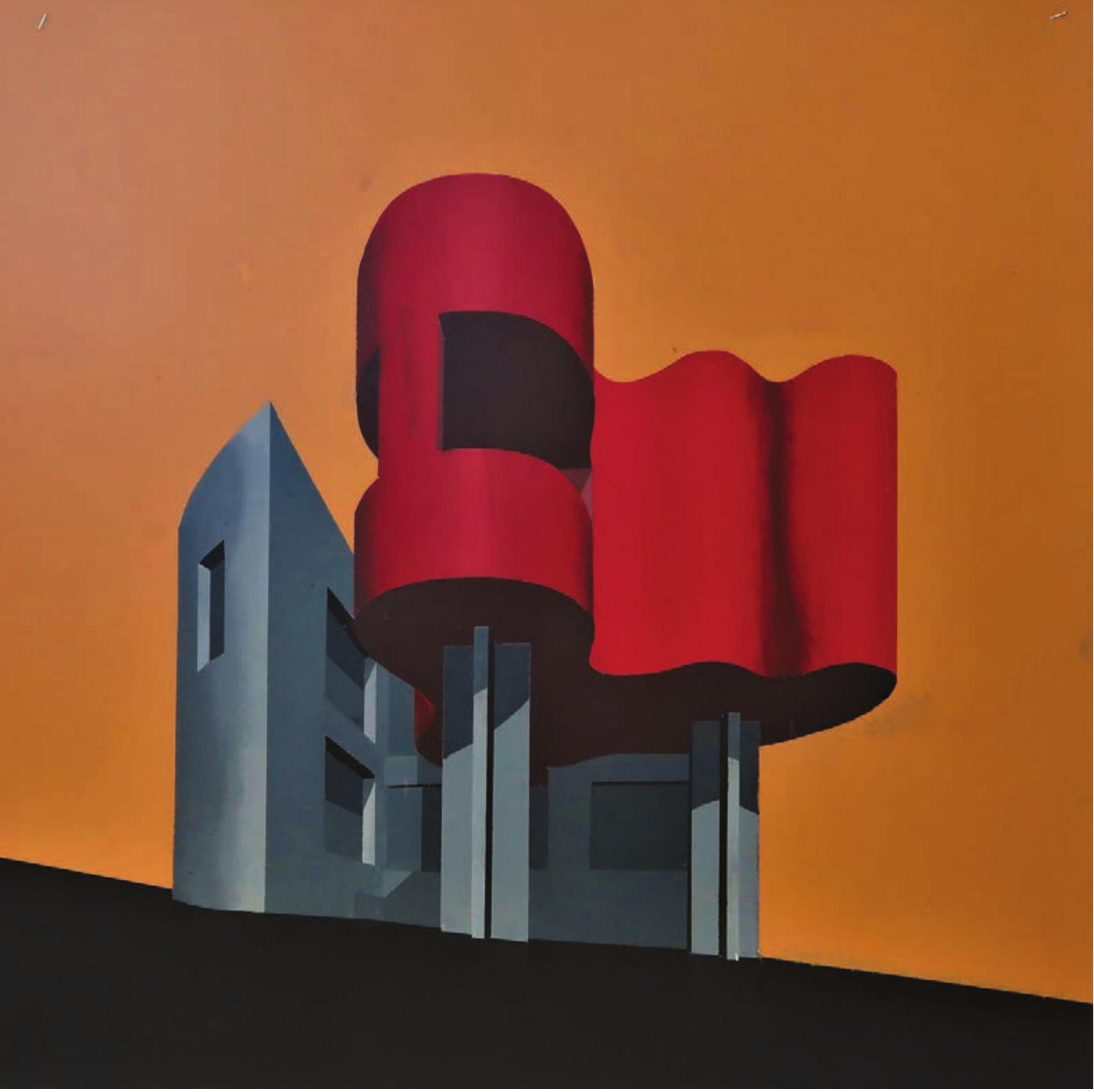

TATSIANA HUDZINOVICH 